\title{
Ponovno odkritje dvoma o ikoni: študija izmišljenega primera iz prestolnice nekdanje sovjetske države
}

Cilj članka so opredelitev in obravnava radikalnih družbeno-kulturnih pristopov oblikovanja pokrajine v današnjih megamestih znotraj strogega kapitalističnega konteksta ter razpravljanje o njih. $\mathrm{V}$ ta namen je v članku teoretično in na primeru preučen prostorski izraz znotraj vsiljenega sodobnega foucaultovskega »stanja znanosti «. V okviru raziskovalne metodologije sta tako sočasno uporabljeni različni hipotezi, ki naj bi premostili vrzel med teoretičnim preučevanjem in stvarnim vidikom arhitekturnega ustvarjanja. Glavna hipoteza temelji na lacanovskem konceptu dvoma. V članku je dvom upoštevan kot chomskyjanska primitivna sila, ki oblikuje vsakršno zamisel ali koncept in lahko pokvari »radikalno imaginacijo « vsake družbe, kot jo v svojih delih opredeljuje Castoriadis. Druga glavna hipoteza temelji na analitični študiji ustvarjanja prostora znotraj strogih političnih in gospodarskih kontekstov, $\mathrm{v}$ okviru katere so na primeru nekdanje Sovjetske zveze preučene vrednote kulturne pokrajine v komunističnem in kapitalističnem režimu. Največ pozornosti se posveča Armeniji in zlasti preobrazbi pokrajine v prestolnici Erevan med prehodom iz komunizma v kapitalizem. V članku so najprej podrobno teo- retično obravnavani neekonomski dejavniki, na podlagi katerih bi morale kapitalistične države upoštevati potrebe socialno šibkejših družbenih skupin, ki nimajo prostora $\mathrm{v}$ današnjih megamestih, nato pa je podrobno predstavljena izvirna zasnova pokrajine v okviru novejšega arhitekturnega natečaja, ki ga tu razumemo kot sodobno foucaultovsko »stanje znanosti«. Glavni cilj predstavljene arhitekturne zasnove je izpolnitev razpisnih pogojev in pri tem združitev vsiljene podobe globalnega kapitalizma z lokalnimi prvinami. Pri tem naj bi se oblikovala foucaultovska heterotopija, in sicer tako, da se različnim družbeno-kulturnim identitetam omogoči, da razpravljajo o predlagani ikonični prostorski podobi, jo izpodbijajo ali vanjo podvomijo. Avtorja v članku ponudita nov pristop h konceptu dvoma, ki ga obravnavata kot pozitivno prvino »arhitekturne prakse «, in predlagata njegovo stalno prisotnost v idejni razsežnosti arhitekture.

Ključne besede: dvom, kulturna pokrajina, navidezna pokrajina, preureditev, radikalna imaginacija, Erevan, Armenija 


\section{Uvod}

Avtorja v članku najprej preučita, v kolikšni meri se v arhitekturnih postopkih dvomi v foucaultovsko $\gg$ stanje znanosti « v posameznih zgodovinskih obdobjih. To »stanje znanosti «, ki je značilno za vsako zgodovinsko obdobje, družbo usmerja, da z arhitekturo ustvarja simbole, s katerimi se identificira skozi čas. Poleg tega je gospodarsko-politična organizacija družb v človeški zgodovini arhitekturo usmerjala $\mathrm{k}$ odpravljanju temeljnega dvoma, povezanega s primitivno arhitekturno dejavnostjo. Glavni namen članka je zato na novo umestiti arhitekturo v sodobni okvir $\mathrm{z}$ obnovo koncepta $\gg$ dvoma «. $\mathrm{Z}$ upoštevanjem prostorske interpretacije »radikalne imaginacije « Marie Kaika (2011) se na podlagi definicije Corneliusa Castoriadisa poskuša razumeti in ovrednotiti vpliv novih vzorcev rekonceptualizacije na oblikovanje urbanega prostora in pokrajine, ki jih zahtevajo nadnacionalna središča odločanja in ustanove.

Z izbiro Erevana kot območja raziskave, upoštevanjem sovjetskega obdobja te prestolnice in osredotočanjem na njeno posovjetsko obdobje je v članku preučeno, kako je bila prostorska proizvodnja usmerjena v organizacijo družbenega življenja, da bi z uradnim in neuradnim državnim načrtovanjem služila prevladujočim interesom posameznega zgodovinskega obdobja. V raziskavi se zlasti preučuje, kako lahko prehod iz sovjetskega v liberalni kapitalistični sistem vpliva na kulturno pokrajino mesta z oblikovanjem »navideznih pokrajinskih « podob (Mavromatidis, 2010), da bi imelo mesto v sodobnem kontekstu globalizacije pozitivno podobo. Namen izmišljene arhitekturne zasnove, predstavljene v članku, je obogatiti razpravo o tem, kako lahko strokovnjaki s področja kulture, arhitekti in urbanisti prispevajo $\mathrm{k} \gg$ ustvarjanju lokalnega duha in simboličnih kategorij, kot sta ,globalno in ,lokalno' v obdobju družbenih sprememb « (Molnar, 2011: 283) in gospodarske krize. Da bi pritegnili domače in tuje vlagatelje, je oblikovanje nove »navidezne pokrajine « (Mavromatidis, 2010) v mestu postalo najpomembnejše. Pri tem so arhitekti vse pogosteje vpleteni kot oblikovalci tovrstnih podob in nosilci odločanja.

Osnovno sodobno orodje neuradnega državnega načrtovanja so mednarodni arhitekturni natečaji, ki ponazarjajo in kažejo, kako se »strokovno znanje prevaja v politično moč, čeprav arhitekti nimajo nadzora nad oprijemljivimi političnimi in gospodarskimi viri (Molnar, 2011: 285), ali kako med kriznimi obdobji arhitektura družbo uči, »česa naj si želi in kako naj si tega želi« (Žižek, 1989, navedeno v Kaika, 2010: 458), tako da deluje kot del »radikalne imaginacije «, kot o tem razmišlja Castoriadis (Kaika, 2010). V članku je opisana izvirna stvaritev, katere cilj je oblikovati mrežo dvomov o tem, ali je mogoče $\mathrm{z}$ različnimi arhitekturnimi natečaji in gradbenimi projekti, ki se lahko lotevajo tudi kulturnega vidika različnih zgodovin- skih plasti, oblikovati model prostorske proizvodnje, katerega glavni cilj je utrditi vsiljeno podobo globalnega kapitalizma z lokalnimi prvinami, in tako ustvariti heterotopijo (Foucault, 1993).

Da bi se izognili nepravilnemu teoretiziranju o neekonomskih dejavnikih te študije ter nejasni teoretski konceptualizaciji in prostorski analizi, se raziskava opira na empirične podatke. $\mathrm{Na}$ podlagi metodološkega pristopa Marie Kaika (2010) članek za razširitev kritičnega okvira preučuje proizvodnjo arhitekture, ljudje, ki živijo $\mathrm{v}$ preučevanem arhitekturnem prostoru kot pomembni akterji in raziskovalni subjekti (to je arhitekti, načrtovalci in nosilci odločanja), pa so bili povabljeni, naj izrazijo svoje mnenje. Opravljeno je bilo 200 petminutnih anonimnih telefonskih pogovorov $\mathrm{z}$ naključno izbranimi prebivalci Erevana (100 žensk in 100 moških). Empirični del raziskave se je najprej osredotočil na javno dojemanje »dvoma « (rus. сомнения), nato pa tudi na polemike glede ustvarjanja nove podobe » navidezne pokrajine « v Erevanu (rus. виртууальныцй ландшафm) $)^{[1]}$. Čeprav seznam anketirancev ni obsežen, je ta del raziskave izredno pomemben, saj preučuje več vidikov erevanske resničnosti, da bi pridobili mnenja ljudi, katerih večina (60\% anketirancev) je živela v dveh različnih gospodarskih in organizacijskih sistemih zadnjega stoletja.

\section{Ustvarjanje}

\author{
Ti si nebeška ptica; \\ živiš v moji lobanji, \\ moji možgani te hranijo \\ in samo zato obstajaš. \\ (Hionis, 2010: 39)
}

Čeprav danes velja, da človeški um rojeva in hrani misli, ideje in pojme, je obenem izredno težko določiti prvobitno silo, ki človeško naravo spodbuja $\mathrm{k}$ dejanju ustvarjanja. $\mathrm{V}$ filozofiji je ta sila lahko notranja ali zunanja (za podrobnosti glej Foucault-Chomsky, $\left.1974^{[2]}\right)$. Po Chomskem obstaja instinktivno znanje ali oblika, ki posamezniku omogoča, da iz delnih podatkov ustvari kompleksno zavedanje; to znanje je osnovna sestavina človeške narave. Foucault pa dvomi v pojem človeške narave in meni, da je ta prvobitna sila zunanja in da lahko problem ustvarjalnosti oblikujemo tako, da upoštevamo stanje znanosti, v katero je postavljen.

Čeprav ne dvomimo v pojem človeške narave, ne moremo zanikati dejstva, da uveljavljeni arhitekturni koncepti razkrivajo skoraj erotičen odnos med arhitekturo in gospodarsko-političnim kontekstom. Na podlagi Castoriadisovega razmišljanja Kaika (2011) meni, da je vsaka družba sčasoma oblikovala svoje ikonične arhitekturne objekte, ki so »skozi zgodovino 
postali totemi posameznega družbenega reda oziroma del sistema pomenov, ki opredeljuje kolektivnost te družbe« (Castoriadis, 1987, navedeno v Kaika, 2011: 972). Kar poznamo pod pojmom kolektivna identiteta, ni neodvisna entiteta, temveč neekonomska struktura, ki se oblikuje znotraj določenega ekonomskega okvira, $\mathrm{v}$ katerem $\gg$ socialno, kulturno in institucionalno poteka gospodarska dejavnost « (Hadjimichalis, 2006: 692). S priznavanjem, da je arhitektura prostorska oblika kolektivne identitete, lahko trdimo, da se je na podlagi tega erotičnega odnosa med gospodarsko-političnimi interesi vsakega zgodovinskega obdobja in prostorsko proizvodnjo razvila nova opredelitev načrtovanja pojmov, in sicer ločeno od arhitekture. Norman in Susan Fainstein (1985: 492) sta načrtovanje opredelila kot $\gg$ obliko odločanja, ki zavedno pojasnjuje svojo logiko, navadno s strokovnimi izrazi, poskuša predvideti spremembe v organizacijskem okolju in vzpostavlja daljnosežne strategije za čim boljše doseganje organizacijskih ciljev «.

Za boljše razumevanje tega, kako je prišlo do te ločitve, spomnimo, da je v človeški zgodovini gospodarsko-politična organiziranost družbe poskušala v človeško vedênje vnesti pravila in obvladati človeško naravo (zlasti intelektualni vidik dvoma) z oblikovanjem mreže verskih, etičnih, gospodarskih, političnih in kulturnih gotovosti. Če upoštevamo, da je arhitektura predvsem sposobnost ljudi, da zgradijo zatočišče pred zunanjimi pogoji, lahko trdimo, da se je arhitektura razvila iz primitivnega dvoma zaradi svoje umetniške razsežnosti v zvezi z estetsko in uporabno primernostjo tedanjih naravnih oblik. Na podlagi definicije Normana in Susan Fainsten in ob upoštevanju, da narava arhitekture temelji na nenehnem dvomu o prostorskih oblikah, ki obdajajo človeško razsežnost, lahko sklepamo, da je načrtovanje negativ arhitekture, kot je odločitev negativ dvoma. Trdimo lahko, da je namen arhitekture najti pravilna prostorska vprašanja, medtem ko je načrtovanje usmerjeno $\mathrm{k}$ zagotavljanju posameznih odgovorov in rešitev.

$\mathrm{Na}$ družbeni organizacijski ravni je bila arhitektura prisiljena izgubiti intelektualni status dvoma z oblikovanjem tega foucaltovskega stanja znanosti, katerega cilj sta bila racionalno organiziranje družbenega življenja in ugajanje prevladujočim interesom posameznega zgodovinskega obdobja prek uradnega ali neuradnega državnega načrtovanja (za več podatkov glej Davidoff, 1965; Gans, 1968; Castells, 1977, 1978, 1996; Harloe, 1977; Harvey, 1978; Stone in Harpham, 1982; Holton, 1984; Fainstein in Fainstein, 1985; Sklair, 2005; Hadjimichalis in Hudson, 2006). S preoblikovanjem v prakso odločanja izgublja arhitektura vidik dvoma oziroma » negotovost, odprto stanje, pri katerem je še vse mogoče in ni nobena možnost izključena « (Žižek, 1998: 75). ${ }^{[3]}$

\section{Pokrajina v Erevanu in prehod iz komunizma v kapitalizem}

Po tej kratki analizi literature o ustvarjanju sledi analiza posebnosti preučevanega območja. $V$ članku arhitekturo razumemo kot vmesno disciplino, pri kateri bi moral arhitekt povezati filozofsko in sociološko znanje, da bi ustvaril prostor in ne ovojev zgradb. Skozi Erevan teče reka Hrazdan in od leta 1918 oziroma zlasti odkar »se je na tisoče tistih, ki so preživeli armenski genocid, naselilo na tem območju «, velja za industrijsko, kulturno in upravno središče Armenije (Katsenelinboigen, 1990: 78). V vsej armenski zgodovini je njegova družbena, kulturna in ekonomska prevlada močno vplivala na vso državo. $\mathrm{V}$ zadnjih letih se je zaradi gospodarske rasti podoba pokrajine v mestu spremenila, saj od leta $2000 \mathrm{v}$ mnogih mestnih predelih nastajajo novogradnje. Erevan je bilo prvo mesto v Sovjetski zvezi, za katero so izdelali glavni načrt. V Sovjetski zvezi je postalo pomembno znanstveno in kulturno središče, ki se je spremenilo v moderno industrijsko metropolo $\mathrm{z}$ več kot milijonom prebivalcev. Aleksander Tamanjan je ustvaril sovjetsko različico mesta tako, da je vanj s sovjetskimi urbanimi in pokrajinskimi stvaritvami vključil tradicionalne nacionalne prvine (slika 1). Da bi ustvarili popolno sovjetsko mesto, so izbrisali številne sledi preteklosti in porušili zgodovinske zgradbe, med njimi perzijsko trdnjavo, cerkve, mošeje, karavanseraje, bazarje in kopališča.

Kot navaja Iván Szelényi (1984), se zdi, da v praksi vse komunistične države vstopijo $\mathrm{v}$ fazo nenaravne rasti, $\mathrm{v}$ kateri industrializacija poteka hitreje kot $\mathrm{v}$ mnogih kapitalističnih gospodarstvih na enaki ravni gospodarske razvitosti. Lászlo Kulcsár in Tamás Domokos (2005) pa menita, da je za poenotenje prostorskih in družbenih struktur komunistični razvoj vztrajal pri odpravljanju podedovanih neenakosti z državnim načrtovanjem, zaradi česar so ostro nasprotovali iskanju lokalne identitete in lokalni organiziranosti. Ti argumenti lahko teoretično pojasnijo, zakaj so zanemarili starodavno kulturno pokrajino mesta z dolgo zgodovino. Želeli so namreč mesto utrditi kot politično in kulturno središče nove sovjetske regije. To dejstvo razkriva splošno mnenje, da je teritorialno načrtovanje nujno povezano $\mathrm{z}$ urbanističnim načrtovanjem in da pomembno vpliva na kulturno pokrajino, saj se osredotoča na rabo tal (Mavromatidis, 2010). Čeprav je ta obsežni urbanistični načrt uspel razširiti podobo mesta v sovjetskem svetu, je obenem kraj spremenil v nekakšen nevtralni prostor za prebivalce armenske prestolnice, saj je bil po osnovni logiki osrednjega komunističnega razvoja vsakršen poskus samoorganizacije grožnja političnemu sistemu (Kulcsár in Domokos, 2005).

David Canter (1977) meni, da moramo poznati pojme in tudi pomene, ki jih ljudje povezujejo z lokacijo in s fizični- 


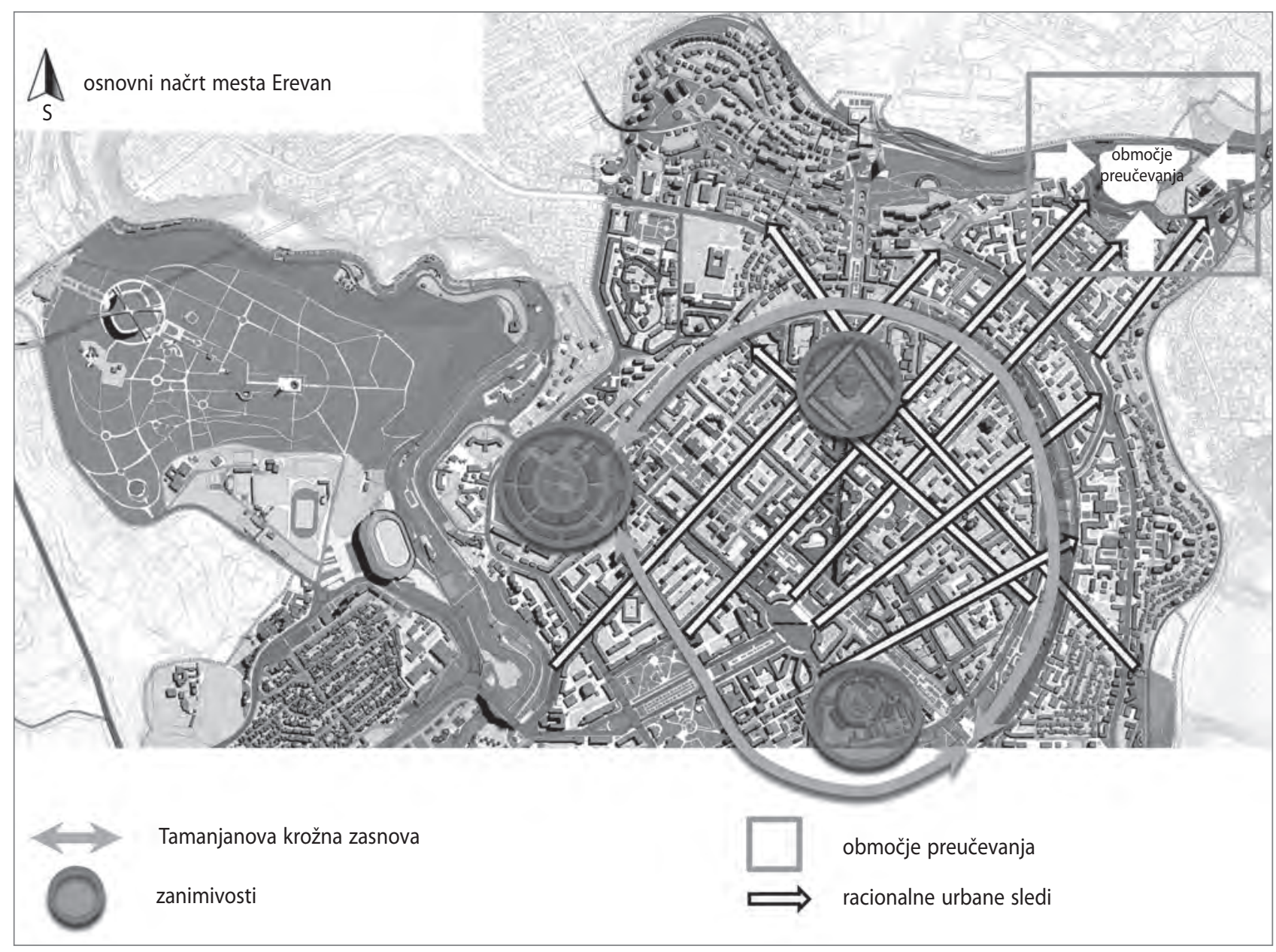

Slika 1: Analiza osnovnega načrta osrednjega erevanskega okrožja, ki razkriva krožno zasnovo Tamanjanovega načrrta. Območje te raziskave je označeno v zgornjem levem kotu načrta (ilustracija: Hanna Mangasarian in Lazaros E. Mavromatidis).

mi lastnostmi prostora, da bi lahko razumeli določen kraj. Empirični podatki so to prepričanje potrdili, saj so skoraj vsi anketiranci pojem občutka prostora povezovali s spomini po otroštvu, na primer na dom staršev (rus. pодительскийдом), domače dvorišče (rus. pодительский двор) ali domovino (rus. poдuнa). Ko je značaj majhnega mesta ogrožen zaradi izgube pomembnih okoljskih značilnosti, lahko v skupnosti teoretično pride tudi do izgube občutka navezanosti na grajeno in naravno okolje ter njegove stalnosti in trajnosti (Brown in Perkins, 1992). To dejstvo tudi dokazuje, da je industrializacija v komunizmu vplivala na psihologijo ljudi, saj so se prebivalci preseljevali s podeželja v industrijska mestna središča, kar je sčasoma pri ljudeh vzbudilo nostalgijo po podeželskem življenju iz otroštva.

Erevan je to povezavo s preteklostjo sicer izgubil, vendar je nastala nova povezava s skupnim sovjetskim imenovalcem, in sicer tako, da so ohranjali vsiljeni občutek pripadnosti skupnosti. V sovjetski Armeniji je sistem vrednot spodbujal organizacijo družbenega življenja znotraj skupnosti. $\mathrm{V}$ tem novem obdobju se je v mestu pojavilo ogromno nove infrastrukture, ki jo je osrednja vlada uvozila v novi načrt mesta, na primer muzeji, tovarne in obsežni stanovanjski bloki z ogromnimi trgi in urbanimi povezavami (slika 2). Na tem mestu spomnimo, da je tovrstno večanje merila, ki je potekalo v sovjetskih časih, spremenilo urbani prostor in kulturno pokrajino.

Erevan je postal prestolnica Republike Armenije po razpadu Sovjetske zveze leta 1991. Novonastala republika finančno ni zmogla zagotoviti zanesljive dobave elektrike in plina, kar je vplivalo na negativno podobo armenske prestolnice in armenskega gospodarstva po svetu. Kot trdi Harvey Molotch (1996: 229), » pozitivna povezava med podobo izdelka in krajem ustvari nekakšen monopol, ki se drži krajev, njihovih oznak in blagovnih znamk, povezanih z njimi . Z vidika trženjske komunikacije imajo podobe znotraj okvira globalizacije pomembno trženjsko vlogo pri ustvarjanju navidezne pokrajine (Mavromatidis, 2010), saj vplivajo na zaznavanje in različne prostorske odločitve, ki jih po Eliju Avrahamu (2000) sprejmejo te tri skupine: splošna javnost, nosilci odločanja na nacionalni in mednarodni ravni ter lokalni prebivalci.

Zaradi slabo načrtovanega in izpeljanega prehoda $\mathrm{v}$ tržno gospodarstvo se je v prvih letih po razpadu Sovjetske zveze 

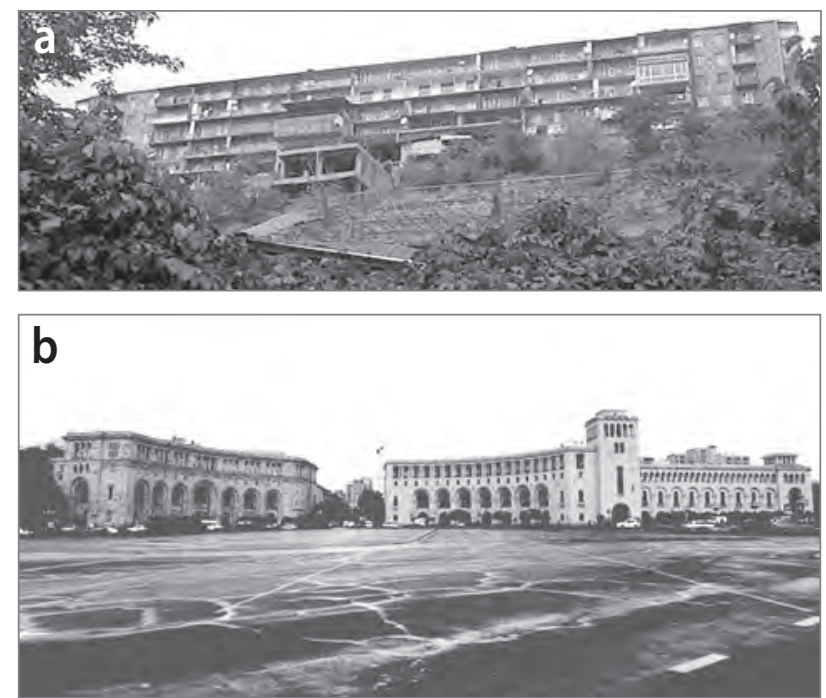

Slika 2: (a) Komunalna stanovanja v Erevanu oblikujejo kulturno pokrajino, ki je nastala s preureditvijo mesta v obdobju Sovjetske zveze. (b) Javne zgradbe in javna mesta s kulturno pokrajino, ki jo oblikujejo, neposredno izražajo moč režima. Današnji Trg republike se je nekoč imenoval Leninov trg, na njem pa je v sovjetskih časih stal velik Leninov spomenik. Na desni sta poslopji zunanjega ministrstva in ministrstva za energetiko, na levi pa hotel Armenija, ki je v obdobju Sovjetske zveze slovel kot najbolj luksuzni hotel v mestu (foto: Hanna Mangasarian).

oblikovala podoba gospodarsko šibke države. Ob upoštevanju mnenja Anselma L. Straussa (1961), ki je trdil, da se pri razpravah o mestih ta običajno stereotipizirajo, so številni raziskovalci ugotovili, da se zaradi tovrstnega ustvarjanja stereotipov spremembe ne izražajo v podobah krajev (Graber, 1989; Elizur, 1994; Avraham, 2000).

Anketiranci pa menijo, da se je po letu 2000 mesto spremenilo $\mathrm{v}$ veliko gradbišče z žerjavi, ki so postavljeni po vsem okrožju Kentron. Številne večnadstropne stavbe so uradno del velikopoteznega urbanističnega načrtovanja. Več raziskovalcev je preučevalo pojem kulturnega gospodarstva kapitalističnih mest, pri čemer se je poudarjalo, da je njegov cilj komercializacija zgodovinske dediščine in velikopotezno javno vlaganje, ki bi spodbujalo skupno kulturno porabo kot posledico urbane prenove (Wynne, 1992; Bassett, 1993; Moulinier, 1996; Scott, 1997; Ntaras, 2001). Kot trdi Sasha Tsenkova (2011), načrtovalci in oblikovalci politike za države $v$ tranziciji neposredno uporabljajo zahodnoevropske razvojne modele. Zlasti v zvezi z nekdanjimi državami Sovjetske zveze več raziskovalcev meni, da je politična tradicija nekdanjih sovjetskih držav močno vplivala na oblikovanje drugačnega odnosa med državo in družbo v pokomunističnem obdobju (za več podatkov glej Chirot, 1989; Schöpflin, 1993; Janos, 2000; Berend, 2003; Kulcsár in Domokos, 2005). Kot trdita Kulcsár in Domokos (2005), je ta sprememba posledica nenehnega tekmovanja lokalnih elit z drugimi območji za prerazporeditev virov, da bi s tem okrepile in ohranile lokalno oblast $\mathrm{v}$ komunizmu.
Poleg tega je sodobno postmoderno kapitalistično »stanje znanosti « v svetu oblikovalo mrežo, v kateri mesta pozivajo, naj z odnosi z javnostjo in s promocijskimi dejavnostmi vplivajo na svojo navidezno podobo pokrajine v medijih, čeprav ne morejo nadzirati družbeno-kulturnih razmer, uredniških odločitev in večine družbeno-kulturnih identitet (Avraham, 2000). Ciljno občinstvo v sodobni globalizirani mreži so turisti, pripadniki novega vǐ̌jega srednjega razreda (mednarodnega ali lokalnega) in podjetja. Politična usmeritev želi z zadovoljevanjem potrebe po fantazmičnem zapeljevanju ustvariti nov metropolitanski življenjski slog za pripadnike srednjega in višjega dohodkovnega razreda (Žižek, 1989; navedeno v Kaika, 2011: 985), in sicer na podlagi arhitekturne proizvodnje, kot to nakazujejo izsledki Marie Kaika (2011). Kljub temu Kulcsár in Domokos (2005) ter nekateri anketiranci navajajo, da so pokomunistični družbeni stroški dobro skriti, zaradi česar je razvoj potekal v izredno spodbudnem okolju. Ni naključje, da so anketiranci pojem razvoja povezovali predvsem s tehnologijo (rus. технология), $\mathrm{z}$ rastjo (rus. pocm) in višino (rus. вbcoma), ne pa tudi z obnovo družbenih vrednot.

Kot navaja Kevin R. Cox (1995), je po drugi strani »zelo verjetno, da bodo strategije lokalnega gospodarskega razvoja za privabljanje posla v konkurenčnem okolju prenašale in celo podpirale neenakosti pri razporejanju ugodnosti «. Zato se lahko zgodi, da se bosta dve glavni družbeno-kulturni identiteti, ki jih Konstantinos Ntaras (2001) imenuje »kozmopolitanizem « in »ekskluzionizem «, pojavili tudi v Erevanu in ogrozili njegovo kulturno pokrajino. Stopnja prihodka je prevladujoči dejavnik, zaradi katerega želijo višji dohodkovni razredi ustvariti življenjski slog na podlagi novih porabniških vzorcev, v tem primeru pa obstaja resnična nevarnost, da se ta navidezna pokrajina sčasoma preoblikuje $\mathrm{v}$ novo kulturno pokrajino in tako uniči družbeno-kulturno identiteto kraja. Koliko se lahko ta navidezna pokrajina asimilira, je odvisno od družbeno-gospodarske prihodnosti države. Če bo ta novi metropolitanski življenjski slog prevladal, bo preteklost odstranjena iz podobe mestne pokrajine.

\section{S ponovnim odkritjem ikone nova tržna usmeritev vpliva na »kulturno pokrajino« nove metropole v svetu}

Zadnji ambiciozni projekt mestne občine Erevan je bil razpis odprtega mednarodnega natečaja, ki ga je v sodelovanju z več armenskimi ministrstvi ter $\mathrm{v}$ skladu $\mathrm{z}$ Unescovimi pravili in odobritvijo mednarodne zveze arhitektov (ang. International Union of Architects, v nadaljevanju: IUA) organizirala in oglaševala multinacionalka, ki je simbol proizvodnje luksuznih avtomobilov. Cilj natečaja, kot je bil opisan v programu in pogojih, je bilo »uresničenje novega in izvirnega projekta ra- 


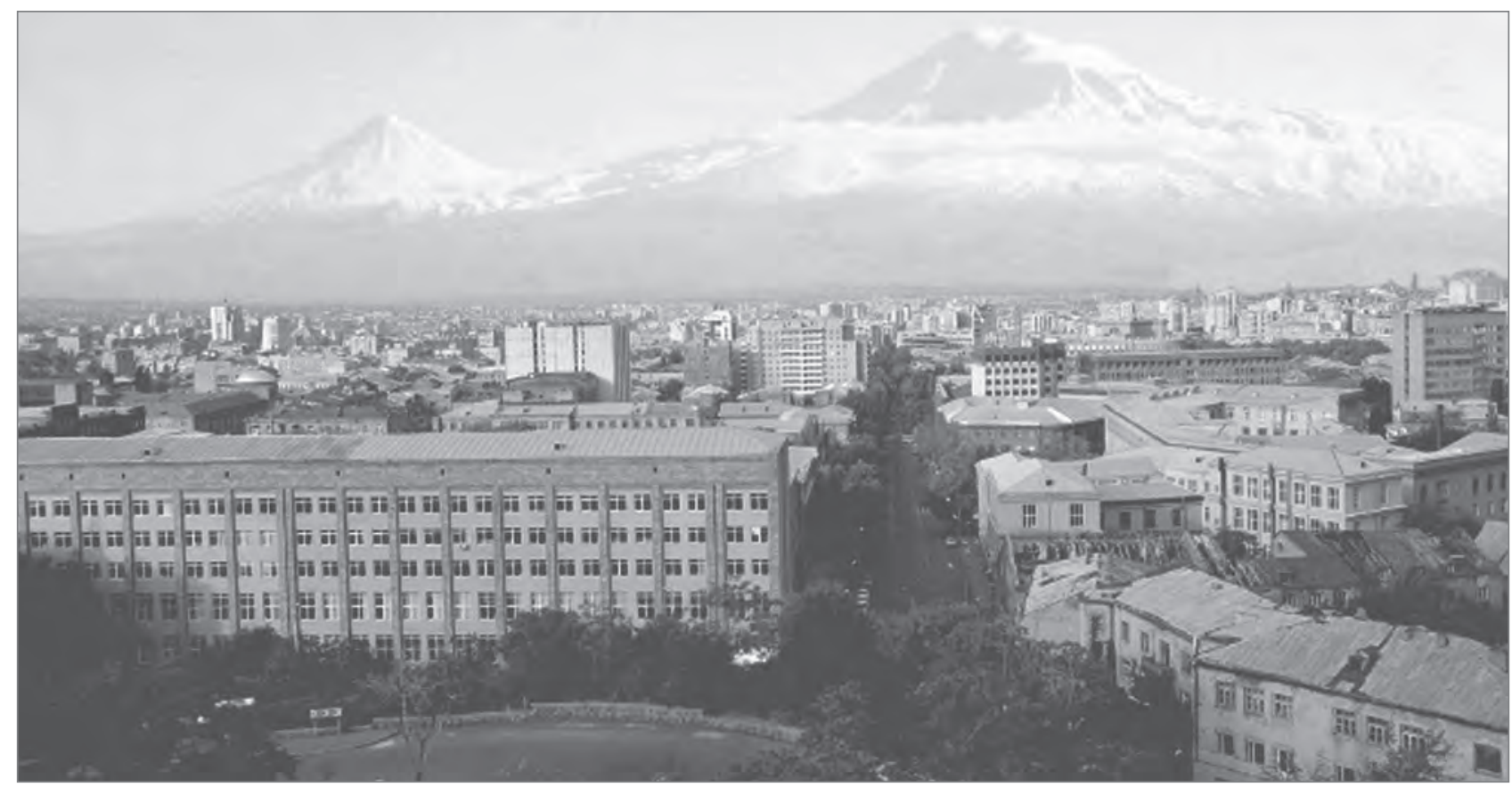

Slika 3: Pogled s projektne lokacije na goro Ararat proti jugu (foto: Hanna Mangasarian)

zvoja mesta, ki bo arhitekturno in funkcionalno vključen « v okoliško mestno pokrajino. Ta »izvirni projekt razvoja mesta « naj bi vključeval luksuzni hotel in poslovno središče, $\mathrm{v}$ vsakem primeru pa je to morala biti »arhitekturna rešitev, ki bo vidna z vsake točke v mestu «, saj naj bi postala nov ikonični simbol mesta. Ker je bil ta večnamenski kompleks za organizatorje izjemno pomemben, je bil predviden v obliki obsežnega središča, $h$ kateremu bi bile usmerjene vse glavne mestne ceste. Poleg tega so organizatorji zahtevali, da mora hotel stati na južni strani projektnega območja in da mora čim več sob gledati neposredno na mesto. Po mnenju organizacijskega odbora naj bi bil hotel kot arhitekturna rešitev zaradi lokacije in obsega viden z vsake točke $\mathrm{v}$ mestu, obenem pa bi bil tudi $\gg$ tisti del celotnega kompleksa, ki vzbuja kar največ pozornosti«. Poleg tega naj bi v skladu z zahtevami zgradili tudi stanovanjsko stavbo, usmerjeno proti jugu, s stanovanji najvišje kakovosti in z vso opremo, ki omogoča visoko stopnjo udobja. Če upoštevamo, da naj bi se gradilo na vzpenjajoči se 4,4 ha veliki ploščadi, obdani z glavnimi cestami ter $s$ panoramskim razgledom na mestno središče in goro Ararat, lahko razumemo pomen in razsežnost tovrstne stvaritve v pokrajini (slika 3).

$S$ trženjskega vidika razpis tega natečaja izraža željo po oblikovanju podobe gospodarske oživitve. Sodelovanje med IUA in dvema ministrstvoma, Unescova odobritev vsebine natečaja, celotna organizacija in mednarodni razpis brezplačno večajo mednarodno prepoznavnost $s$ kulturnimi vidiki v pokrajinski podobi mesta. Besede in izrazi, kot so »del kompleksa, ki pritegne pozornost «, »arhitekturna rešitev, vidna z vsake točke $\mathrm{v}$ mestu « in »večnamenski kompleks «, kažejo značilnosti prostrane umetne pokrajine (Mavromatidis, 2010). Erevan se nahaja na potresno ogroženem območju in konstrukcija bi morala prenesti potres moči 9,0 na Richterjevi lestvici. Po drugi strani pa bi moral biti luksuzni hotel visok $101 \mathrm{~m}$. Kaže, da je namen tega urbanističnega in arhitekturnega projekta ustvariti grajeno pokrajino, ki bo ikonični simbol armenske gospodarske in tehnološke moči. Ali to protislovje med protipotresno varnostjo in višino $\mathrm{v}$ naših predstavah ustvarja podobo sodobnega visokotehnološkega megamesta kot simbola moči? Da bi lahko odgovorili na to vprašanje, moramo uporabiti pojem »velikega Drugega « (Žižek, 1989), ki je pojasnjen v nadaljevanju.

\section{Oblikovanje mreže dvomov v zvezi s paradoksom avtoritete za ponovno odkritje ikone}

Po tej kratki analizi problema si predstavljajmo, da na natečaju sodelujemo kot arhitekti in se spopadamo z različnimi vprašanji, ki jih zastavljajo natečajni pogoji in družbeno-kulturne razmere v Armeniji. V članku je pojem dvoma razumljen kot chomskyjanska primitivna sila, ki rojeva vse ideje in koncepte za oblikovanje Castoriadisove radikalne imaginacije vsake družbe. Na drugi strani imamo foucaultovsko stanje znanosti, ki jo gospodarski in politični dejavniki vzpostavljajo zato, da bi nadzorovali neekonomske dejavnike družbene realnosti. $\mathrm{Za}$ razlago tega, $s$ katerimi psihološkimi mehanizmi lahko foucaultovsko stanje znanosti posameznega zgodovinskega obdobja preobrazi ali izbriše intelektualno razsežnost dvoma, uporabljamo Lacanovo strukturo velikega Drugega (za podrobnejšo analizo glej Žižek 1989, 1998). Danes bi le redki oporekali trditvi, da ima pojem dvoma negativno intelektualno 
razsežnost, in sicer zaradi kulturnega statusa današnjih družb, pri katerem mora biti posameznik o nečem dobro prepričan, da lahko dokaže svojo samozavest drugim; vse to privede do znanja velikega Drugega. ${ }^{[4]}$ Empirični izsledki so potrdili negativno podobo dvoma v družbeni imaginaciji, mnogi anketiranci pa so dvom povezovali z negotovostjo (rus. неуверенность), nevarnostjo (rus. onасность), s strahom, da ne bodo našli službe (rus. найти работу), ali psihološkim mehanizmom, ki posamezniku omogoča preživetje (rus. возможность выљжить). ${ }^{[5]}$ Ker so arhitekti del družbe, so v to igro vstopili in odpravili postopek dvomljenja tako, da so predstavili dokončne projekte, ki simbolizirajo moč in gotovost. $V$ članku se poskuša ta dipol med dvomom in stanjem znanosti prikazati z vpogledom $\mathrm{v}$ resničen primer arhitekturne prakse, ki se začne $\mathrm{z}$ analizo objektivnih prostorskih podatkov in konča s predlogom arhitekturne kompozicije, ki smo jo prvič v zgodovini umestili v postopek dvomljenja o tem, kaj je prav ali narobe. Glavni cilj je ponovno odkriti arhitektovo subjektivnost, pri čemer uporablja dvom kot glavno orodje.

$\mathrm{V}$ tej študiji pa zahteve projektne naloge ne moremo upravičiti z njenim prvobitnim kontekstom in vsebino. Kaj je torej razlog za njeno skrito avtoriteto, izraženo v obliki mednarodnega arhitekturnega natečaja? Pri psihološki razlagi se opiramo na Kierkergaardovo trditev, da je » končna in edina utemeljitev izjave avtoritete njeno lastno dejanje artikulacije « (Kierkegaard, 1962: 100). V našem primeru okvir natečaja tvori avtoriteta, ki jo podpira neposredni fizični pritisk, saj tisto, s čimer se arhitekt ukvarja, ni avtoriteta $\mathrm{v}$ pravem pomenu besede, ampak preprosto delovanje surove nemočne sile (Žižek, 1992), izražene z določenimi natečajnimi pravili. Po Žižkovem (1992) mnenju pa ima avtoriteta paradoksalni vidik in zato je v naši študiji projektna naloga zelo prepričljiv klic, ki arhitekta ne more prisiliti v ničesar, vendar se zaradi nekakšnega podzavestnega pritiska čuti dolžnega, da mu brezpogojno sledi zato, ker ima to stanje znanosti avtoriteto, in ne zato, ker bi bila njegova vsebina pravilna, modra ali globoka.

Arhitekt $s$ tem, ko sledi navodilom avtoritete, odpravi svoj dvom in tako nezavedno preide iz subjektivnosti v objektivnost. Po predstavitvi izsledkov analize $\mathrm{v}$ prejšnjem poglavju pa se pojavi vprašanje, zakaj vedno obstaja nevarnost, da bo arhitekt slepo sledil zahtevam projektne naloge, ne da bi poskušal oblikovati mrežo dvomov in tako spodbijal njeno pravo razsežnost $\mathrm{z}$ argumenti. ${ }^{[6]} \mathrm{Za}$ razlago tega položaja se lahko, kolikor nam je znano, opremo samo na Žižkovo analizo lacanovske strukture velikega Drugega, pri čemer veliki Drugi nima zahtevanega družbeno priznanega znanja, da bi lahko podvomil v stanje znanosti, ki ga je vzpostavila avtoriteta (v našem primeru je to projektna naloga natečaja), ${ }^{[7]}$ zato mu slepo sledi.

Čeprav je jasno, da posamezen arhitekt ne more odločati o urbani usmerjenosti središč odločanja, pa lahko poskuša ekonom- ske direktive in usmeritve preoblikovati v potencialne stvaritve kulturne pokrajine $\mathrm{z}$ dvomljenjem. Teoretična in terenska raziskava je pokazala, da je prvobitno vprašanje izraženo s potrebo po »upoštevanju možnosti lokalnih skupnosti pri upravljanju mest za reševanje družbenih neenakosti « (Erkip, 2000). Z anketami smo ugotovili, da je pokomunistična zapuščina vsiljenega egalitarizma, ki ga je uvedla temeljna logika komunističnega obdobja, dejstvo, da ljudi veliko bolj zanima izražanje svojega prej zatrtega individualizma. Posledično zaradi zgoraj omenjenih dejavnikov struktura velikega Drugega pri osebi, ki je med komunizmom živela znotraj komunističnega stanja znanosti, občutek pripadnosti skupnosti dojema negativno.

V nasprotju s tem pri nas, dejavnih arhitektih, ki živimo in razmišljamo v okviru kapitalističnega individualizma, struktura velikega Drugega pripadnost skupnosti dojema kot nekaj popolnoma pozitivnega. Poleg tega smo del kapitalistične družbe, ki se je znašla v krizi, zato se naša radikalna imaginacija premika v smeri skupnostnega občutka estetske proizvodnje. Za posameznika, ki je živel v vsiljeni skupnosti, pa je njegova radikalna imaginacija neločljivo povezana $\mathrm{z}$ individualnimi estetskimi vzorci. Mogoče je prvi korak k doseganju ravnovesja pri oblikovanju združitev globalne prvine (luksuzni hotel) z lokalnim vidikom na istem območju tako, da poskušamo ozemlje spremeniti v prostor. Morda je v tem kontekstu dvoma edina rešitev upoštevanje mnenja Dine Vaiou in oblikovanje projekta »na konici noža « »na podlagi vmesnosti: med lokalnim in mednarodnim, zunaj in znotraj, med izoliranostjo in stikom, vzhodom in zahodom, moškim in žensko, zanimanjem in brezbrižnostjo« (Vaiou, 2004: 531).

\section{Oblikovanje predloga: artikulacija pokrajine in osnovni elementi stvaritve}

V kompoziciji, ki je bila oblikovana na podlagi naše analize, je pokrajina razdeljena na tri dele, oblikovane glede na specifične potrebe posameznega dela programa in osebni cilj sledenja strategiji mešanja prebivalstva, kar naj bi ustvarilo pregleden prostor, odprt za stanovalce ter domače in tuje obiskovalce. Odločitev za upoštevanje strategije mešanja prebivalstva je pravzaprav poskus, ki je posledica osebne potrebe po nasprotovanju strogemu stanju znanosti natečaja, ki ne upošteva neekonomskih dejavnikov. Trije glavni deli kompozicije so hotelska stavba, stanovanjski kompleks s knjižnico, kinodvoranami in $\mathrm{z}$ gledališči ter vmesna poslovna stavba $\mathrm{z}$ razstavnimi in s konferenčnimi prostori ter kulturno usmeritvijo. $\mathrm{V}$ skladu z našim predlogom naj bi stanovanjska stavba postala večnamenski objekt za vse mesto (umetnike, znanstvenike in študente), ki bo odprt za vse prebivalce Erevana. V skladu z načelom mešanja prebivalstva predlagamo, naj se 50 \% stano- 

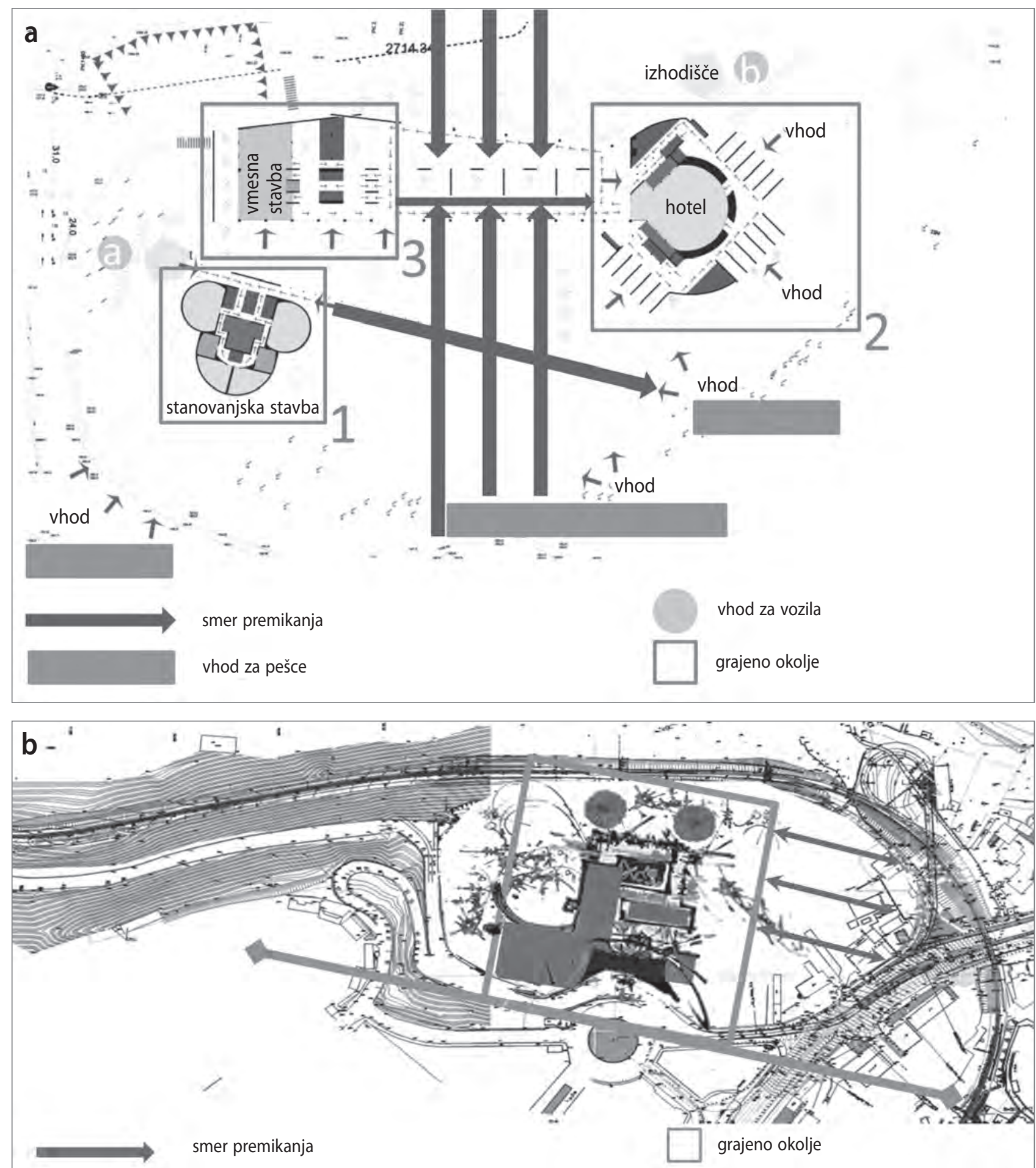

Slika 4: (a) [Odobreni cilj] Smer premikanja po območju - premikanje obiskovalcev naj bi z oblikovanjem »pregledne pokrajine« že samo postalo pravi spektakel. (b) [Zavrnjeni cilj] Če slepo sledimo natečajnim pravilom, moramo grajeno okolje postaviti na sredo območja. $\mathrm{S}$ tem pa hotelski kompleks moti skladno in transparentno smer gibanja. Na ta način bi bila ikonična podoba hotela najopaznejša prvina kompleksa, vendar bi delovala kot pregrada v mestni podobi, ker bi bila postavljena na sredo območja (ilustracije: Lazaros E. Mavromatidis).

vanj nameni nepridobitnemu najemu, saj bi tako na območju dosegli socialno ravnovesje in izboljšali socialno dostopnost.

Glavna smer gibanja poteka z mestne ulice v notranjost kompleksa. Kot pravi Kaika (2010), »življenje v mestu še naprej poteka na ravni ulic, kjer se stavbe dotikajo tal«, in zaradi tega se veliko pozornosti posveča ohranjanju povezanosti tega območja z mestnim prostorom (slika 4a). Ob upoštevanju smeri gibanja kot najpomembnejše prvine arhitekturne zasnove lahko zavrnemo rešitve, ki slepo sledijo zahtevam natečaja in hotelski kompleks postavljajo $\mathrm{v}$ središče območja (slika 4b). V skladu s tem glavna vrednost projekta temelji na teoretični 


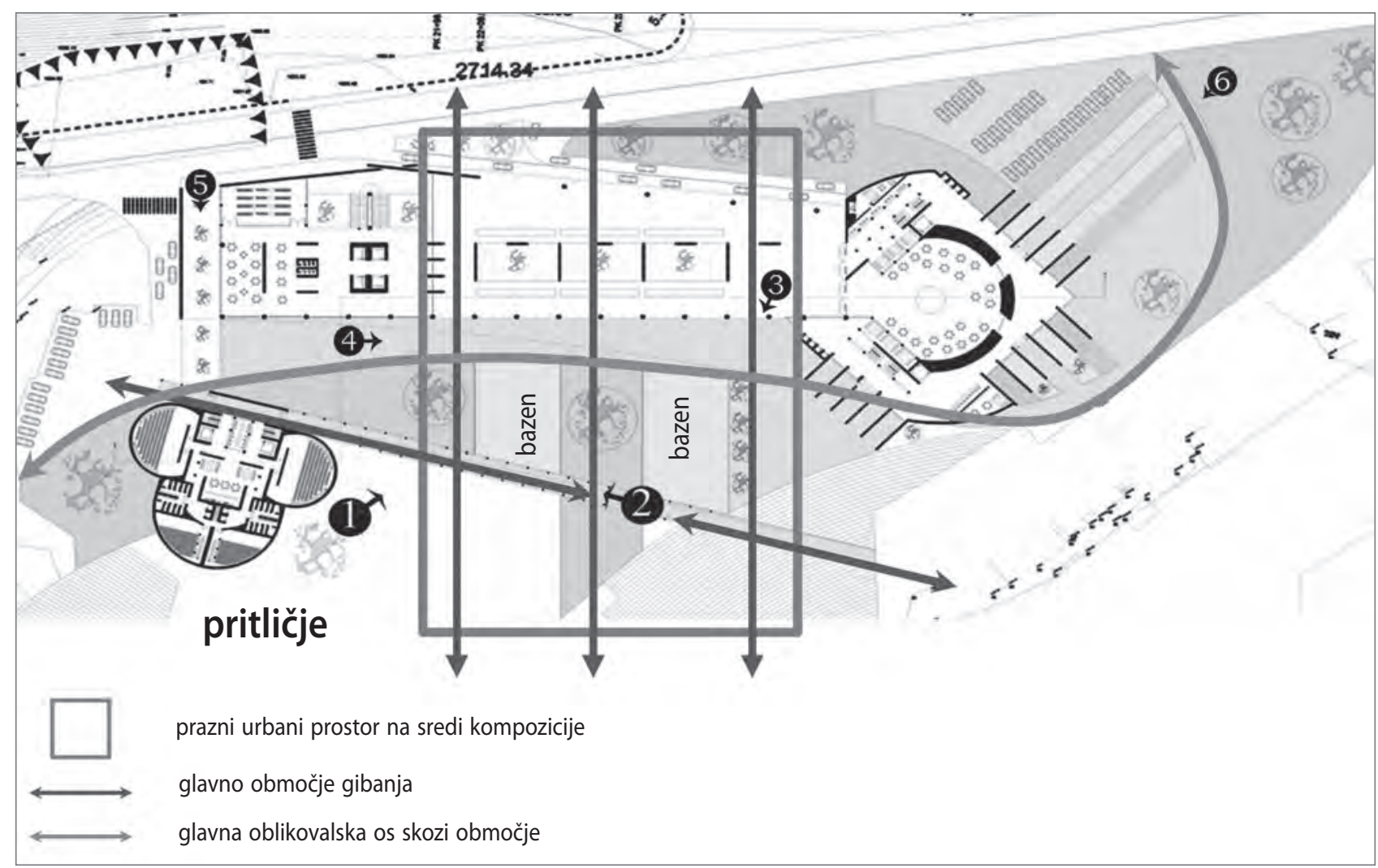

Slika 5: Glavni namen tega predloga krajinskega oblikovanja je ponovno združiti prazno območje znotraj meja mesta z njegovimi urbanimi sledmi, in sicer z vzpostavitvijo dialoga med notranjimi in zunanjimi elementi pokrajine, kar bi ustvarilo interakcijo med domačimi in tujimi obiskovalci in tako spodbudilo estetske izboljšave (ilustracija: Lazaros E. Mavromatidis).

domnevi, da bi morala biti nova pokrajinska prvina oblikovana v skladu s posameznimi značilnostmi kraja, obenem pa bi moral biti cilj tudi doseganje vidne harmonije in sklenjenosti danega urbanega tkiva (Abel, 1997). V tem pogledu sta izhodišče obiskovalcev krožni atrij v hotelskem kompleksu (odprt vsakomur) in knjižnica s prostim dostopom, ki je del stanovanjske stavbe. Premikanje v kompleks z različnimi objekti in skozenj je pomemben vidik arhitekture in krajinskega oblikovanja (slika 5). Z vidika krajinskega oblikovanja je navdušujoče dejstvo, da projekt in topografija omogočata interakcijo med domačimi in tujimi obiskovalci pri vstopu $\mathrm{v}$ zgradbo $\mathrm{v}$ vmesnem nadstropju (slika 6).

V skladu s tem je glavni namen te postavitve ponovna združitev notranjega dela stavbe z mestnim utripom, kot da bi zunanjost prestavili v notranjost, kar dosežemo z oblikovanjem več notranjih prostorov in poti (slika 7). $\mathrm{V}$ tej notranji pokrajini nismo slepo sledili estetskim pravilom kompozicije, različna višina posameznih delov kompleksov pa razkriva funkcionalno logiko razporeditve in organizacije notranjosti. Vsak objekt je oblikovan iz strukturnega ogrodja in idejnih ovojev, določenih $s$ funkcionalnimi pravili coniranja, tako da je vsak del kompleksa dostopen vsakomur.

Temeljna logika posameznega poslopja je tako izražena s pročelji in izpolnjuje zahtevo po odpornosti proti potresu z mo-
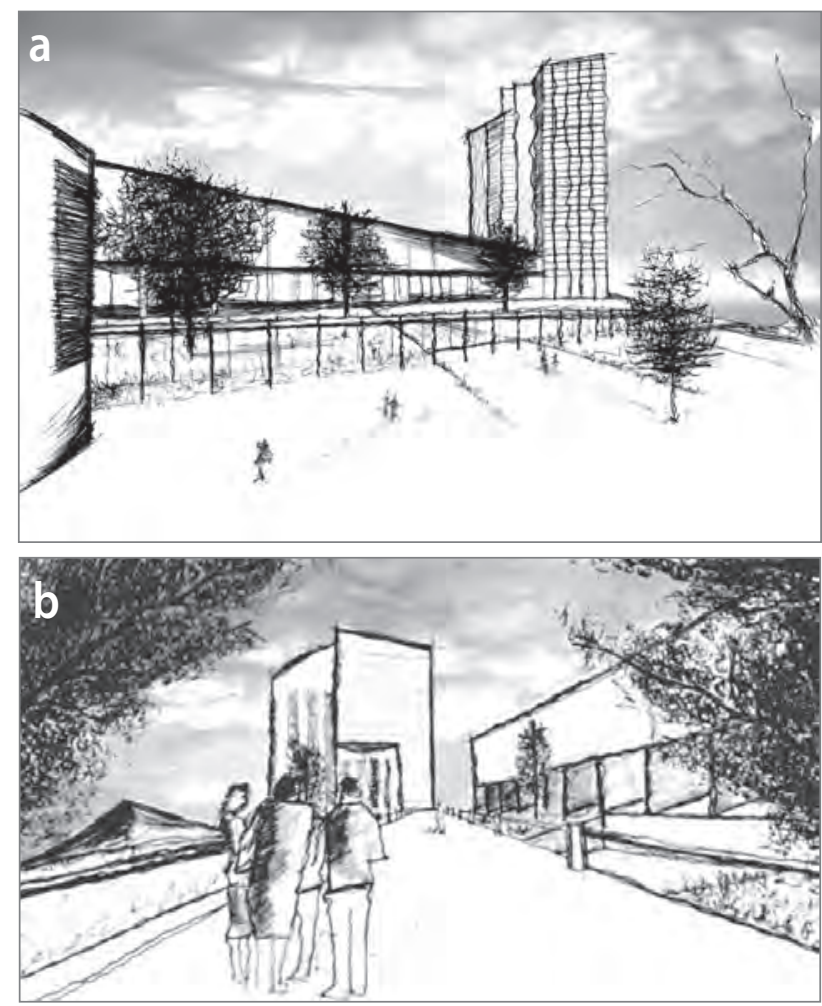

Slika 6: Prikaz načrtovane pokrajine: (a) gledano točke 1 na sliki 5; (b) gledano s točke 2 na sliki 5 (ilustracije: Lazaros E. Mavromatidis). 


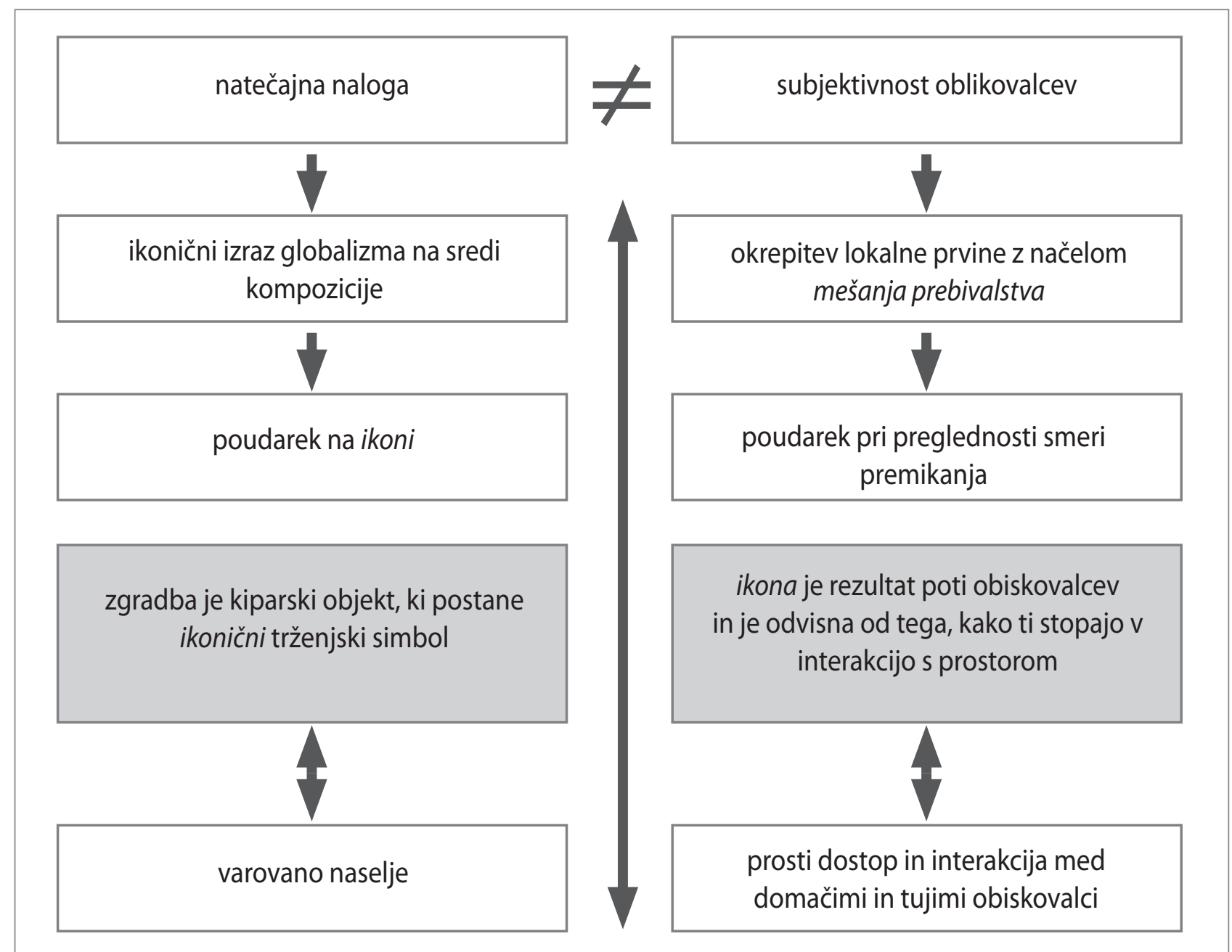

Slika 7: Shematski prikaz glavnih idejnih razlik med subjektivno razsežnostjo avtorjev in natečajno nalogo (ilustracija: Lazaros E. Mavromatidis)

čjo 9,0 na Richterjevi lestvici. V tem primeru kompleks izraža novo opredelitev krajinske prvine $\mathrm{z}$ vidika potresne varnosti. Konstrukcijski in funkcionalni sistem je preprost in sestavljen iz ponavljajočih se celic, razporejenih po pravilni betonski strukturi. V središču kompozicije je vmesna poslovna stavba, opremljena s konferenčnimi in z razstavnimi dvoranami. Temelji so na podpornikih, ki slonijo na mreži stebrov. Ti zago-

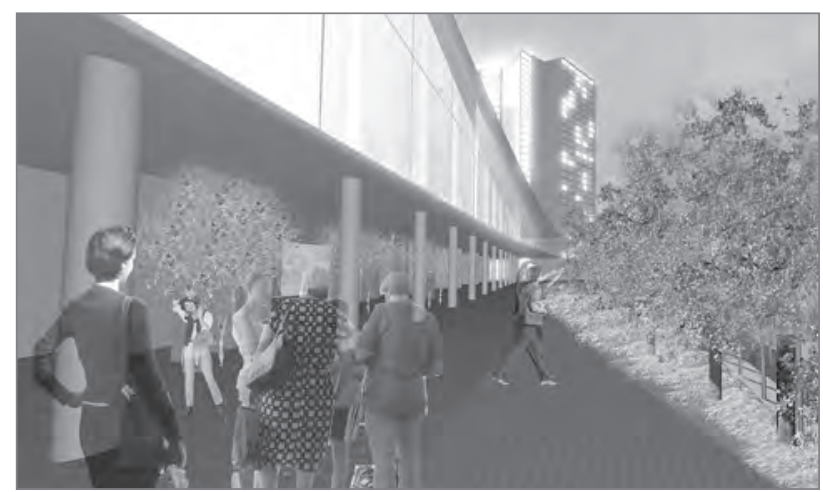

Slika 8: Pogled s točke 3 na sliki 5 - v ozadju je vidna hotelska stavba (ilustracija: Asimina Mavromatidi). tavljajo odpornost proti potresom z močjo 9,0 na Richterjevi lestvici (slika 8). Na tej višini so vhod, začasni razstavni prostori in vsi spremljajoči objekti kulturnega središča, odprtega za vse državljane (slika 9).

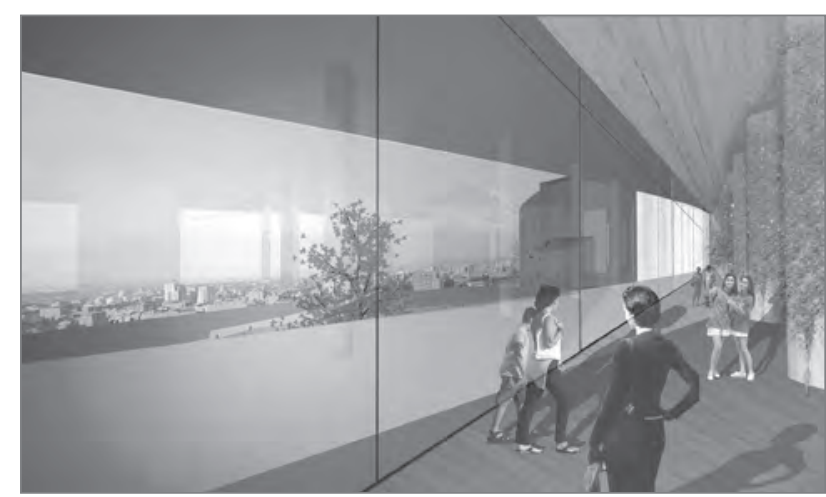

Slika 9: Pogled s točke 4 na sliki 5 - pogled na goro Ararat iz notranjosti vmesne stavbe, v katero lahko vstopi vsak (ilustracija: Asimina Mavromatidi). 


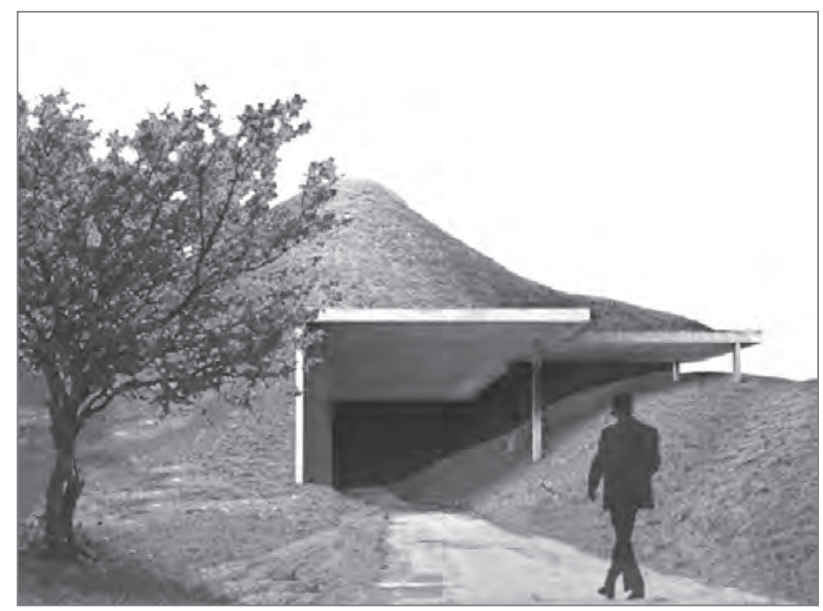

Slika 10: Pogled s točke 5 na sliki 5 - smer premikanja obiskovalcev ni edina linearna pot, zato morajo obiskovalci poiskati več različnih vhodov, skozi katere lahko vstopijo na to območje (ilustracija: Asimina Mavromatidi).

\section{Sklepi: rekviem za sanje oziroma želja po oblikovanju heterotopije}

$\mathrm{V}$ tej študiji mednarodni poslovni center v Erevanu in hotel nista razumljena kot kiparska objekta, ampak kot notranja trasa ali mesto, ki ljudi vodi skozi novo in preprosto kulturno pokrajino $z$ domačimi in $s$ tujimi značilnostmi. Zunanjost vsake zgradbe izraža njene notranje lastnosti. Poleg tega trasa ni samo en linearni niz z natančno določenim začetkom, sredino in koncem, ampak sestoji iz več poti, do katerih lahko ljudje dostopajo in jih zapustijo na različnih točkah; je v nenehnem dialogu z naravnimi prvinami pokrajine in izraža dvom v možnost vsiljene deterministične ravni gibanja (slika 10).

Po Foucaultu lahko prostori, ki niso združljivi in ustvarjajo družbene odnose, ki spodbijajo uveljavljeni socialni okvir in resničnost, oblikujejo heterotopijo (Foucault, 1993). Predlagana nova pokrajina v Erevanu naj ne bi bila enotna celota, ampak naj bi postala heterotopija. Združuje tri značilne vrste gradnje z različno družbeno usmeritvijo: izstopajoči arhitekturni element (hotelski kompleks), kot ga zahteva natečaj, simbolično vmesno stavbo z lastnostmi tovarne in velikim številom kulturnih prostorov ter stanovanjsko poslopje, ki ima tudi družbeno-kulturna območja. Da bi lahko kompleks ustvaril heterotopijo, mora biti odprt in dostopen vsakomur, ki želi obiskati začasne razstave in konference (balkon kompleksa). Tudi zato ima nova sekundarna večnamenska stavba različne prostore in vmesne dele (stanovanjsko poslopje $s$ knjižnico, kinodvorano, z restavracijo in gledalǐ̌či).

V tej študiji arhitektura nastopa kot strategija urbanističnega in krajinskega oblikovanja in ne v svojem formalističnem smislu. Omejitve lokacije, geološke razmere, natečajna naloga in funkcionalna pravila coniranja pa tudi neekonomski družbe-

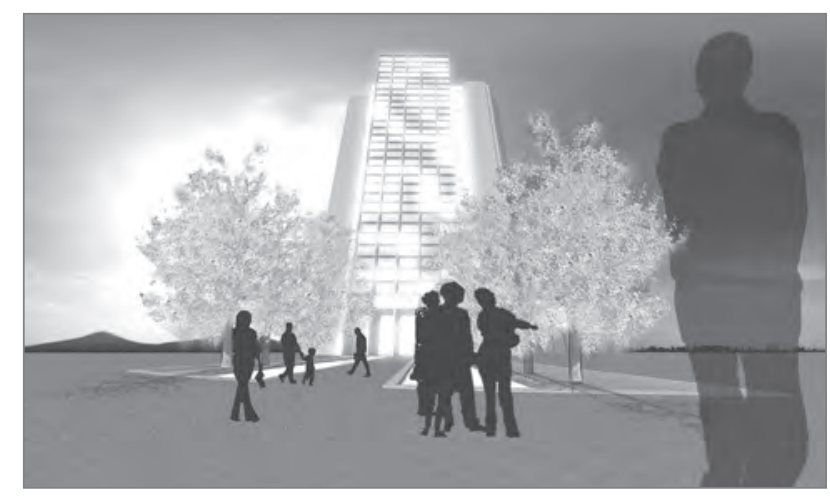

Slika 11: Pogled s točke 6 na sliki 5 - omejitve lokacije, geološke razmere, natečajna naloga in neekonomski družbeno-kulturni elementi tega mesta zahtevajo oblikovanje minimalističnega in preprostega zunanjega modela. Zaradi zmanjšane ikonične podobe stavbe pa ima obiskovalec lep razgled $z$ vsake točke kompleksa. Na levi vidi goro Ararat, čeprav stoji pred hotelom z debelimi zidovi, visokim 101 meter (ilustracija: Asimina Mavromatidi).

no-kulturni elementi tega mesta zahtevajo oblikovanje minimalističnega in preprostega zunanjega modela. Če preučujemo tradicionalno armensko arhitekturo, ugotovimo, da je preprostost $\mathrm{v}$ armenski filozofiji ustvarjanja pravzaprav izražena z minimalizmom, saj izvira iz potresno ogroženega območja in se zato oblikuje z upoštevanjem te nevarnosti. Armenske stavbe so navadno nizke in imajo debele zidove (slika 11). Zaradi tega se v tradicionalni armenski arhitekturi za gradnjo čvrstih minimalističnih stavb uporablja posebna vrsta betona.

Glavni cilj je omogočiti, da se lahko v okviru družbeno-kulturnih identitet tega mesta odloča, ali se bo novonastalo območje v mestni zavesti staralo elegantno in ali bo vanj vključeno za oblikovanje prave kulturne pokrajine, kar bi ga hkrati preoblikovalo $\mathrm{v}$ prostor in kraj.

Kot kažejo izsledki raziskave o oblikovanju politike, ki jo je izvedel David L. Prytherch (2003), posamezni arhitekti ne morejo usmerjati zapletenega političnega ozračja, $v$ katerem je zemljišče, ki naj bi se urbaniziralo in je namenjeno prihodnosti določenega mesta ( $v$ tem primeru Erevana), tudi simbol njegove preteklosti. Lahko pa uporabi več družbenih praks, ki niso usmerjene samo v ekonomsko proizvodnjo, ampak tudi v neekonomske dejavnike, kot sta kulturna tradicija in regionalna identiteta, da preoblikuje prihodnji obseg urbanega življenja in ponovno odkrije ikonični vidik skozi proces stalnega dvomljenja. Strategija mešanja prebivalstva, predlagana za stanovanjsko stavbo, uporaba betona in kovine za doseganje preprostosti v oblikovanju in oblikovanje več odprtih kulturnih prostorov skupaj z jasnim in s preglednim gibanjem znotraj in zunaj stavb $\mathrm{v}$ tem kompleksu brez izhodišc in končnih točk so cilji, katerih namen je ustvariti dvom $\mathrm{v}$ formalističnost arhitekture.

Za ponovno odkritje ikoničnosti prostora je uporabljen njegov dostop do družbeno-kulturnih identitet kot glavni vir navdiha, 
ki lahko gradi na tem, kar Castoriadis opredeljuje kot radikalno imaginacijo. Na podlagi razumevanja bistva tukaj predstavljene različice je ikona rezultat poti obiskovalcev in odvisna od tega, kako bodo ti vstopili v interakcijo z oblikovanim prostorom. Zaradi tega ponuja rešitev več nezasedenih prostorov, tako da se lahko obiskovalci počutijo svobodni in prostor preoblikujejo v skladu s svojimi željami in navadami. Zgradba ni kiparski objekt, vendar pa ima nezasedeni prostor kiparsko naravo, saj lahko uporabniki spreminjajo geometrijo, način nastanitve in obseg osebnih posegov. Čeprav gre za študijo, ki ne bo uresničena v praksi, bi lahko imel zgoraj opisani pristop realne posledice na konkretni in ne le teoretični ravni samo, če središča odločanja dovolijo njegov obstoj. Zato so glavni nameni projekta določitev, izpogajanje in začetek razprave o radikalnih arhitekturnih pristopih $\mathrm{k}$ oblikovanju pokrajine $\mathrm{v}$ današnjih megamestih znotraj strogega kapitalističnega okvira, ne pa predlaganje pravilnega in osnovnega načina dojemanja in razumevanja ikone prihodnje realnosti.

Lazaros Elias Mavromatidis

Ecole Nationale Supérieure d'Architecture de Lyon, Laboratoire MAP-ARIA UMR CNRS-MCC 3495, Lyon, Francija

E-pošta: lazarosmavr@hotmail.com

Asimina Mavromatidi

National Technical University of Athens, Faculty of Architecture,

Atene, Grčija

E-pošta: semimavr@gmail.com

\section{Opombe}

${ }^{[1]}$ Ankete so bile opravljene v ruščini, saj se je v Sovjetski zvezi poučevala v armenskih šolah in jo zato ljudje še vedno tekoče govorijo (je drugi uradni jezik v državi). Izvajale so se od 1. februarja do 25 . avgusta 2011. Prevedla jih je Anna Bykalyuk.

${ }^{[2]}$ Več podatkov je na voljo $\mathrm{v}$ razpravi med Michelom Foucaultom in Noamom Chomskim, ki je $v$ angleščini in francoščini potekala na tehnološki univerzi v Eindhovnu in je bila posneta za nizozemsko televizijo (Chomsky in Foucault, 1971).

[3] Za boljše razumevanje delovanja tega človekovega psihološkega mehanizma lahko za primer vzamemo Georgea Clooneyja, ki igra glavno vlogo v filmu Antona Corbijna The American, posnetega po romanu Martina Bootha z naslovom A Very Private Gentleman. Ameriški plačani morilec Jack (Clooney) se po službenem polomu umakne na italijansko podeželje. Ker ne želi ponovno izzivati usode, sprejme še zadnje naročilo, in sicer naj bi za skrivnostno Mathilde sestavil posebno pištolo. $V$ tem zanj neznačilno mirnem obdobju se zaplete z lepo prostitutko Claro. Muči pa ga sum, da ga nekdo namerava ubiti, in pri tem sumi, da Clara obvešča njegove sovražnike o tem, kje se nahaja. Obenem sumi, da ima prste vmes tudi Mathilde, za katero sestavlja orožje. Na koncu spozna, da so bili njegovi sumi glede Mathilde upravičeni, saj ugotovimo, da je ves ta čas zanjo sestavljal pištolo, s katero naj bi ga ubila, Clara pa je bila pri vsem tem popolnoma nedolžna. V skladu z Žižkovo razlago Lacanove teorije $v$ tem trenutku junak pri iskanju odgovora na svoje sume izgubi status dejavnega subjekta in se spremeni v objekt. Današnji arhitekti so kot Jack v Corbijnovem filmu, ki ugotovi, da dela za uradne in neuradne ustanove, obenem pa izgublja svojo moč subjektivnega odločanja.

${ }^{[4]} \mathrm{V}$ tem kratkem prispevku, ki je napisan $v$ obliki razprave, se ne moremo osredotočiti samo na preučevanje psiholoških struktur v smislu izvirnih idej in podrobne analize. Za razumevanje tega, kako ima pojem dvoma negativno vrednost $v$ sodobnem kapitalističnem organizacijskem sistemu, ne smemo pozabiti, kako so se trgi odzvali leta 2010, ko je grški predsednik vlade izrazil dvom v sposobnost Grčije, da odplača svoje dolgove. Poleg tega so vsa ta leta Hollywood in oglasi nezavedno nadzirali velikega Drugega. Ne moremo si na primer predstavljati Marlona Branda ali Brada Pitta polnega dvomov in obenem privlačnega za ženske. Družba, ki temelji na moških vzorcih za krepitev svojega občutka moči, je usmerjena v pripisovanje negativnih vrednosti in definicije dvoma ter pripisovanje pozitivne vrednosti gotovosti.

${ }^{[5]}$ Dejstvo, da ima pojem dvoma negativen predznak v domišljiji ljudi, ki so svojo osebnost oblikovali v komunističnem organizacijskem sistemu, lahko pojasnimo tudi z dejstvom, da je sovjetska družba temeljila na ideji posameznika, ki je dovolj močan, da je lahko o vsem prepričan. $V$ širši ruski kulturi pred komunizmom pa je dvom spodbujal refleksijo (na primer v delih Antona Čehova).

${ }^{[6]}$ Zanimivo je preučiti dela arhitektov na temo kompozicije, ki so na voljo na spletu. 0 tem multikompleksu arhitekturne zasnove pokrajine in njegovem družbeno-kulturnem vplivu niso objavljene nobene razprave, pogosto pa sta omenjeni estetska formalistična predstavitev ikoničnega arhitekturnega dela ter njegova razdelitev na prostore za pomembne goste in skupne prostore, pri čemer naj bi bil ves kompleks varovan z ograjo in tako izoliran od mesta, obenem pa naj bi ohranjal svoje luksuzne značilnosti. Protislovje, ki se tukaj pojavi, je naslednje: čeprav je kompleks strogo ograjen, oblikovalci tovrstnih projektov trdijo, da se kompozicija harmonično zliva z urbanim tkivom.

[7] Za več podatkov glej Žižek (1992: 98-100).

\section{Zahvala}

Najprej se avtorja zahvaljujeta Marii Kaika za pomoč pri začetnem delu za ta članek, za njene koristne komentarje k prejšnjim osnutkom in stalno razpoložljivost. Anonimnim recenzentom se zahvaljujeta za pripombe in koristne predloge. Poleg tega se zahvaljujeta tudi Damianosu Aronidisu, Andreu Kindinisu in Anni Bykalyuk za zaupanje v projekt ter pomoč pri izvedbi in podrobni oceni. Posebna zahvala gre Hanni Mangasarian, ker je dovolila uporabo svojih fotografij. Lazaros Mavromatidis bi rad to delo posvetil Aniouti in se ji tako zahvalil za zaupanje in spodbudo. Oba avtorja se za pomoč zahvaljujeta Eliasu, Stamatini, Assimini in Pinelopi za njihovo spodbudo ter tudi Nikosu, čeprav teh vrstic morda ne bo nikdar prebral. Na koncu bi se rada poklonila spominu na pesnika in prijatelja Argyrisa Hionisa in se od njega poslovila.

\section{Viri in literatura}

Abel, C. (1997): Architecture and identity: Towards a global eco-culture. Oxford, Architectural Press.

Avraham, E. (2000): Cities and their news media images. Cities, 17(5), str. 363-370. DOI: 10.1016/S0264-2751(00)00032-9

Bassett, K. (1993): Urban cultural strategies and urban cultural regeneration: A case study and critique. Environment and Planning A, 25(12), str. 1773-1788. DOI: 10.1068/a251773

Berend, I. T. (1986): The historical evolution of Eastern Europe as a 
region. International Organization, 40(2), str. 329-336. DOI: 10.1017/ S0020818300027168

Brown, B. B., in Perkins, D. D. (1992): Disruptions in place attachment. V: Altman, I., in Low, S. (ur.): Place attachment, str. 279-304. New York, Plenum. DOI: 10.1007/978-1-4684-8753-4_13

Canter, D. (1977): The psychology of place. London, The Architectural Press.

Castells, M. (1977): The urban question: A Marxist approach. Cambridge, MA, MIT Press.

Castells, M. (1978): City, class, and power. London, Macmillan.

Castells, M. (1996): The rise of the network society. London, Blackwell.

Castoriadis, C. (1987): The imaginary institution of society. Cambridge, Polity.

Chirot, D. (ur.) (1989): The origins of backwardness in Eastern Europe Berkeley, University of California Press.

Chomsky, N., in Foucault, M. (1971): Human nature: Justice versus power The Chomsky-Foucault debate. Dostopno na: http://www.chomsky.info (sneto 1. 4. 2012)

Cox, K. R. (1995): Globalisation, competition and the politics of local economic development. Urban Studies, 32(2), str. 213-224. DOI: $10.1080 / 00420989550013059$

Davidoff, P. (1965): Advocacy and pluralism in planning. Journal of the American Institute of Planning, 31(6), str. 331-338. DOI: $10.1080 / 01944366508978187$

Elizur, J. (1994): Israel and the US: Images of flawed paradise. Prispevek je bil predstavljen na konferenci z naslovom American-Israeli Relations and the 'New World Order', ki je potekala 8. junija 1990 v Jeruzalemu v Izraelu. Tipkopis.

Erkip, F. (2000): Global transformations versus local dynamics in Istanbul: Planning in a fragment metropolis. Cities, 17(5), str. 371-377. DOI: 10.1016/S0264-2751(00)00033-0

Fainstein, N. I., in Fainstein, S. S. (1985): Is state planning necessary for capital? The US case. International Journal of Urban and Regional Research, 9(4), str. 485-507. DOI: 10.1111/j.1468-2427.1985.tb00443.x

Foucault, M. (1993): Of other spaces: Utopias and heterotopias. V: Ocman, J. (ur.): Architecture culture 1943-1968: A documentary anthology, str. 420-426. New York, Columbia Books of Architecture/Rizzoli.

Gans, H. J. (1979): Deciding what's news. New York, Random House.

Graber, D. A. (1989): Flashlight coverage: state news on national broadcasts. American Politics Quarterly, 17(3), str. 277-290. DOI: $10.1177 / 1532673 \times 8901700303$

Hadjimichalis, C. (2006): Non-economic factors in economic geography and in 'new regionalism': A sympathetic critique. International Journal of Urban and Regional Research, 30(3), str. 690-704. DOI: 10.1111/j.14682427.2006.00683.x

Hadjimichalis, C., in Hudson, R. (2006): Networks, Regional Development and Democratic Control. International Journal of Urban and Regional Research, 30(4), str. 858-872. DOI: 10.1111/j.14682427.2006.00687.x

Harlow, M. (1977): Captive cities. New York, John Wiley.

Harvey, D. (1978): Planning the ideology of planning. V: Burchell, R., in Sternlieb, G. (ur.): Planning theory in the 1980s, str. 213-233. New Brunswick, CUPR.

Hionis, A. (2010): Everything I describe it describes me; room poetry. Atene, Gavriilides editions.

Holton, R. J. (1984): Cities and the transitions to capitalism and socialism. International Journal of Urban and Regional Research, 8(1), str. 1337. DOI: 10.1111/j.1468-2427.1984.tb00411.x

Janos, A. C. (2000): East central Europe in the modern world: The politics of borderlands from pre- to postcommunism. Palo Alto, Stanford University Press.
Kaika, M. (2010): Architecture and crisis: Re-inventing the icon, re-imag(in)ing London and re-branding the city. Transactions of the Institute of British Geographers, 35(4), str. 453-474. DOI: j.1475-5661.2010.00398.x

Kaika, M. (2011): Autistic architecture: The fall of the icon and the rise of the serial object of architecture. Environment and Planning D: Society and Space, 39(6), str. 968-992. DOI: 10.1068/d16110

Katsenelinboigen, A. (1990): The Soviet Union: Empire, nation and systems. New Brunswick, NJ, Transaction Publishers.

Kierkegaard, S. (1962): The present age. Of the difference between a genius and an apostle. New York, Harper Torchbooks.

Kulcsár, L. J., in Domokos, T. (2005): The post-socialist growth machine: The case of Hungary. International Journal of Urban and Regional Research, 29(3), str. 550-563. DOI: 10.1111/j.1468-2427.2005.00605.x

Mavromatidis, L. (2010): Goutte d'Or: Inside the obscure of the metropolis. Itineraries in a neighborhood in the north of Paris. Geographies, 16(2), str. 147-165

Molnar, V. (2011): The cultural production of locality: Reclaiming the "European city" in post-wall Berlin. International Journal of Urban and Regional Research, 34(2), str. 281-309. DOI: 10.1111/j.14682427.2010.00894.x

Molotch, H. (1996): LA as product: How design works in a regiona economy. V: Scott, A. J., in Soja, E. (ur.) The city: Los Angeles and urban theory at the end of the twentieth century,str. 225-275. Berkeley, University of California Press,

Moulinier, P. (1996): L'état et les équipements culturels (1959-1995). Les Annales de la Recherche Urbaine, 70(1), str 140-147.

Ntaras, K. (2001): Urban cultural identities and globalization: A critical account. Culture \& Communication, 4(1), str. 47-60.

Prytherch, D. L. (2003): Urban planning and a Europe transformed: The landscape politics of scale in Valencia. Cities, 20(6), str. 421-428. DOI: 10.1016/j.cities.2003.08.008

Schöpflin, G. (1993): Politics in Eastern Europe, 1945-1992. Cambridge Blackwell.

Scott, J. A. (1997): The cultural economy of cities. International Journal of Urban and Regional Research, 21(2), str. 323-339. DOI: 10.1111/ j.1468-2427.00075

Sklair, L. (2005): The transnational capitalist class and contemporary architecture in globalizing cities. International Journal of Urban and Regional Research, 29(3), str. 485-500. DOI: 10.1111/j.1468-2427.2005.00601.x Stone, A., in Harpham, E. (1982): The political economy of public policy. Beverly Hills, Sage.

Strauss, A. L. (1961): Image of the American city. New York, The Free Press.

Szelenyi I. (1984): Cities and the problem of the transition: Introduction and rejoinder. International Journal of Urban and Regional Research, 8(1), str. 1-12. DOI: 10.1111/j.1468-2427.1984.tb00410.x

Tsenkova, S. (2011): Potovanje v neznano: strateško prostorsko načrtovanje $v$ posocialističnih mestih [Venturing into unknown territory: Strategic spatial planning in post-communist cities]. Urbani izziv, 22(1) str. 5-21 [83-99]. DOI: 10.5379/urbani-izziv-2011-22-01-001

Vaiou, D. (2004): The contested and negotiated dominance of Anglophone geography in Greece. Geoforum, 35 (1), str. 529-531. DOI: 10.1016/j.geoforum.2004.01.009

Wynne, D. (ur.) (1992): The culture industry. Aldershot, Avebury.

Žižek, S. (1989): The sublime object of ideology. London, Verso.

Žižek, S. (1992): Enjoy your symptom! Jacques Lacan in Hollywood and out. London, Routledge.

Žižek, S. (1998): Tarrying with the negative: Kant, Hegel and the critique of ideology. Durham, Duke University Press. 